\title{
Effect of Sowing Dates on Growth and Yield of Indian Mustard (Brassica juncea L.)
}

\section{Kul Bhushan Mani Tripathi ${ }^{1 *}$, Tarun Gaur ${ }^{1}$, Lovkush Pandey ${ }^{1}$, Ajay Singh ${ }^{2}$, Ankit Tiwari ${ }^{2}$, Ved Prakash ${ }^{3}$, Utkarsh Singh Rathore ${ }^{4}$ and Rohit Kumar Singh ${ }^{5}$}

${ }^{1}$ Department of Agronomy, Rama University Kanpur, Uttar Pradesh, India

${ }^{2}$ KVK, Block Pachpedwa, Balrampur, Uttar Pradesh

${ }^{3}$ Department of Agronomy, Institute of Agricultural Sciences, Banaras Hindu University, Varanasi, Uttar Pradesh

${ }^{4}$ Division of Crop Protection, Indian Institute of Pulses Research, Kanpur, Uttar Pradesh

${ }^{5}$ School of Agriculture Sciences, Career Point University, Kota, Rajasthan

*Corresponding author

\section{A B S T R A C T}

\section{Keywords}

Sowing dates, Varieties, LAI, No. of siliqua, No. of Branches per plant

Article Info

Accepted:

20 December 2020

Available Online:

10 January 2021
A field experiments was conducted during winter seasons of 2018-19 at Agricultural Research Farm of Rama University Kanpur. To study effect of sowing dates on growth and yields of Indian mustard (Brassica junceaL.). Keeping in this view experiment was conducted in Split Plot Design (SPD) with three replications having two factors. First factor comprised of three dates of sowing (15 Oct, 10 Nov. and 05 Dec.) whereas, second factor consist of three Indian mustard varieties viz; Varuna, Narendra rai-1 and Kranti. Results showed that both dates and varieties (10 Nov. and Varuna) superior compare to rest of treatment. However, highest growth attributes (plant height, dry matter accumulation, Days taken to $50 \%$ flowering, number of tillers, LAI and yield and yield attributes (No. of siliqua $(\mathrm{cm})$ per plant, length of siliqua $(\mathrm{cm})$ test weight, seed yield(q/ha) grain yield, stover yield, biological yield, and harvest index) was recorded under 10 Nov. and Varuna variety, and oil character. At Lowest yield recorded under dates and varieties at 15 Oct. followed by 05 Dec. and Narendra rai-1 and Kranti. Among treatment, dates and varieties (10 Nov. and Varuna) showed effectively increasing the growth and yield and enhanced the nitrogen content efficiency and oil content and oil yield.

\section{Introduction}

India is the third largest country in edible oil economy after USA and China. Oilseed crops, such as soybean, mustard, groundnut and sunflower are the major source of edible oils (Uikey, 2017). In India, total oilseeds production is 320.83 lakh tons, and the contribution of rapeseed-mustard is 79.77 lakh tons that ranks second after soybean (137.94 lakh tons) in the India's oilseed economy. Indian mustard (Brassica juncea L.) is predominantly cultivated in the states of Rajasthan, Uttar Pradesh, Haryana, Madhya 
Pradesh, Gujarat, West Bengal, Assam, Bihar and Punjab (DES, 2017). Indian mustard is a temperate as well as tropical climate crop suited a dry and cool weather conditions to attain satisfactory growth parameters. Dry matter accumulation is the important parameter for obtained better growth and yield attributes and yields in the crop which mostly impact by the adopting changing management viz., sowing dates and soil fertility management practices under changing the climate (Singh et al., 2014). Indian mustard is highly sensitive to climate change and soil fertility (Mandal and Sinha, 2004). Sowing time is a nonmonetary input for optimizing the maximum dry matter accumulation and to provide most congenial conditions for maximum light interception and the best utilization of moisture and nutrients to the better plant growth and seed yield (Pattam, 2017, Singh et al., 2011, Meena and Yadav, 2015). India occupies the third position in rapeseed and mustard production in world after Canada and China. In India, during 2013-14, the area of rapeseed-mustard was 6.5 million ha. with the production of 7.8 million tonnes and productivity of $1208 \mathrm{~kg} / \mathrm{ha}$. However, in Uttar Pradesh during the year 2013-14 the area of rapeseed-mustard was 10.26 lakh ha with the production of 11.29 lakh tonnes and productivity of $1110 \mathrm{~kg} / \mathrm{ha}$. (Anonymous, 2013-14). However, oilseeds area and production in the India in 2016-17 at 262.06 lakh hectare and 32.10 million tonnes respectively (DAC, 2017-18).

Rapeseed-Mustard is considerably sensitive to weather as evidenced from the variable response to different dates of sowing (Kumar et al., 2007). Time of sowing is very important for mustard production (Mondal et al., 1999). Optimum sowing time plays an important role to fullyex ploit the genetic potential of a variety as it provides optimum growth conditions such as temperature, light, humidity and rainfall (Iraddi, 2008). The growth phase of the crop should synchronize with optimum environmental conditions for better expression of growth and yield. Chahal et al., (2009) reported highest seed yield in 10th Nov. sowing as compared to 30th October and 25th November sowing.

\section{Materials and Methods}

The experiment was conducted at Agronomy Research Farm, Rama University Mandhna Kanpur (U.P.) The research farm is located in the main campus of the University. Experiment was laid out in split-plot design (SPD). Twelve treatment combinations comprised of four sowing dates and 3 varieties of mustard were tested in split plot design with 4 replications. The dates of sowing were kept in main plots and varieties were kept in sub plots. Details of the experiments are given as under; Soil of that particular field was Silt loam, with $\mathrm{pH}$ 8.2, lower in organic carbon content (0.37) and low in available nitrogen (194.25 kg ha-1) and medium in phosphorous (18.3 kg ha-1) and potash (250.25 kg ha-1). Three varieties viz. Varuna (V1), Narendra Rai-1 (V2) and Kranti (V3) were used to assess their performance fewer than four dates of sowing viz., 15th October $\left(D_{1}\right), 10$ November $\left(D_{2}\right)$ and 5 December $\left(\mathrm{D}_{3}\right)$. The experiment was conducted under Split plot design with four replications in which date of sowing was taken as main plot treatments and varieties were allocated in sub plots. The crop was fertilized with a uniform dose of nitrogen, phosphorus and potassium @ $120 \mathrm{~kg}, 60 \mathrm{~kg}$ and $50 \mathrm{~kg}$ ha-1, respectively. Urea, DAP, and Murate of potash were used as the source of nitrogen, phosphorus and potassium. half dose of nitrogen along with full dose of phosphorus, potassium and sulphur were applied as basal and remaining dose of nitrogen was top dressed into two equal splits. 1 st split was top dressed at 30 DAS and 2nd 
splits at pre flowering stage of the crop. Thinning was done in two phases. In first phase emerging seedlings were thinned out at 25 days after sowing and second phase of thinning was completed at three leaves stage at 45 days after sowing of the crop to maintain the plant to plant distance of $15 \mathrm{~cm}$. Two irrigations were given to the mustard crop. First irrigation was given at 30 days after sowing and second, irrigation was given at flowering stage of the crop. Harvesting of individual plots was done at physiological maturity when siliquae turned brownish. Mainly mustard crop was harvested as soon as $75 \%$ pods turned yellowish brown. The border rows were harvested first thereafter, net plots were harvested. For minimizing the shattering losses, the crop was harvested especially in the morning hours when siliquae are slightly damage with night dew.The bundles of harvested plants were sun dried for few days at threshing floor after proper tagging. The bundle weight of net plot was recorded individually. Threshing was done by wooden sticks and the seed weights from the net plots were recorded. Seed was subtracted from the total produce as to know the stover yield of its each net plot.

\section{Agronomics Parameters}

\section{Growth parameters}

Initial plant population meter ${ }^{-2}$ : Number of plants meter $^{-2}$ were counted from five places (marked with quadrant) in each plot at 20 DAS and average was worked out.

Plant height (cm): Five plants were selected randomly from each net plot and tagged. The height of plant was measured with the help of meter scale from soil surface to apex of the plant at 30th, 60th, 90th days after sowing and at harvest of the crop and averaged value was worked out.
Days taken to 50\% flowering: Days taken to $50 \%$ flower initiation in all the treatments and plots were recorded.

Leaf area index: The leaf area of five plants was measured by automatic leaf area meter at 30th, 60th and 90th days after sowing of the crop. Leaf area index was calculated by the following formula.

Leaf area index $(\mathrm{LAI})=$ leaf area/ ground area $\left(\mathrm{m}^{-2}\right)$

Number of branches plant -1: Five randomly selected plants tagged for plant height were also used for counting the number of branches at 30th, 60th, 90th DAS and at harvest and average was worked out.

Dry matter accumulation (g) plant $^{-1}$ : Five plants were taken randomly from border row at 30, 60, 90 DAS and at harvest of the crop. These plants were collected separately as per treatment. They were first sun dried further the samples were put in an electric oven at $65^{\circ} \mathrm{C}$ temp. to dry till constant weight. Finally, average values were recorded as $\mathrm{g}$ plant $^{-1}$.

\section{Yield and yield attributes}

Number of siliquae plant $^{-1}$ Number of siliquae counted from five randomly tagged plants in each net plot. Counted the total numbers of siliquae of all five plants and averaged value were recorded.

Length of siliqua $(\mathrm{cm})$ : Length of five randomly selected siliquae from main shoot were measured and averaged reported as length of siliqua in centimeter.

Number of seeds siliqua $^{\mathbf{- 1}}$ : Five randomly selected siliqua, measured for length, were threshed and seeds obtained and counted and finally to take the average value was recorded. 
Test weight (g): From the representative sample of 1000 healthy seeds were counted from the produce of each net plot and weighed. Weights of 1000 seeds were recorded in mustard.

Seed yield: From the individual plot, the net plot area was harvested and produce was sun dried. After drying the crop was threshed and cleaned separately. The final weight was recorded in $\mathrm{kg}$ per net plot and finally converted into $\mathrm{kg}$ ha- 1 .

Stover yield: Stover yield was computed by subtracting the seed yield from total produce. Stover yield was recorded in $\mathrm{kg}$ per net plot area and finally converted into $\mathrm{kg}$ ha- 1 .

Harvest index: The ratio of economic yield and biological yield was computed by using following formula (Donald 1962).

Harvesting Index $=$ (Economical Yield /Biological Yield) 100

Oil yield: Oil yield was computed by multiplying the seed yield with oil content. Oil yield was computed by using following formula.

Oil Yield $\left(\mathrm{Kg}^{-1 \text { hac. }}\right)=$ Seed Yield $*$ Oil content / 100

Oil Content: Seed samples were kept in the electric oven at $650 \mathrm{C}$ for removal of moisture thereafter, the seeds were ground in a pestle mortar for extraction of oil. The conventional Soxhlet method was used for estimation of oil (A.O.A.C., 1970). The oil content was also estimated by Oxford Analytical Newport 4000 NMR Oil percent was calculated by using following formula.

Oil Content $=($ Weight of oil Flask + ether extract - weight of flask oil / substance taken) 100
The results of the present investigation entitled "Effect of sowing dates on growth and yield of Indian mustard (Brassica juncea L.) Varieties" $r$ with a view to understand the 'causes' and 'effect' relationship among growth, yield attributes, yield, quality and economics of the mustard crop observed due to dates of sowing and varieties.

\section{Results and Discussion}

\section{Agronomical parameters}

\section{Initial plant population meter $^{-2}$}

Data pertaining to initial plant population meter $^{-2}$ of mustard as affected by dates of sowing and varieties have been presented in Table 4.1. Initial plant population meter ${ }^{-2}$ of mustard was not influenced significantly due to dates of sowing and varieties.

\section{Plant height (cm)}

Data pertaining to plant height of mustard as affected by dates of sowing and varieties recorded at successive growth stages have been presented in Table. 1 and illustrated.

It is evident from the data that plant height increased successively till 90 DAS under different dates of sowing. Different dates of sowing had no significant influence on plant height at 20 DAS. While at 60 DAS, 90 DAS $\&$ at harvest plant height was highest with crop sown on 10 November at par with 05 December and significantly higher.

While lowest value of 15 October. The varieties had no significant influence on plant height at 20 and 30 DAS. The variety Varuna recorded significantly higher plant height at 60, 90 DAS and at harvest as compared to Narendra Rai -1 and Kranti. Interaction between dates of sowing $\mathrm{x}$ varieties was found non-significant on plant height of mustard. 


\section{Days taken to $50 \%$ flowering}

Data pertaining to days taken to $50 \%$ flowering of mustard as affected by date of sowing and varieties have been presented in Table.2.

A critical examination over data obviously reveal that among different date of sowing $15^{\text {th }}$ October recorded higher value of days taken to $50 \%$ flowering followed by 10 November sowing.

Among the varieties Varuna recorded significantly higher value of days taken to $50 \%$ flowering followed by Narendra Rai -1 .

Interaction effect between dates of sowing $\mathrm{x}$ varieties was found non-significant on days taken to $50 \%$ flowering of mustard.

\section{Leaf area index}

Data regarding to leaf area index of mustard as affected by different dates of sowing and varieties recorded at successive growth stages have been presented in Table. 2 and depicted in Fig. 4.

Different dates of sowing under present investigation have no significant influence on the leaf area index at $30 \mathrm{DAS}$. It is quite evident from the data that leaf area index increased successively till 60 DAS under different dates of sowing. Crop sown on $10^{\text {th }}$ November recorded significantly higher leaf area index over $15^{\text {th }}$ October \& $05^{\text {th }}$ December and at par with $15^{\text {th }}$ October at 60 DAS. Similar trends were recorded at successive stages. Delayed, sowing by one month produced lower leaf area index at all the stages of mustard crop.

Different varieties have no significant influence on the leaf area index at 30 DAS. Among the varieties Varuna recorded significantly higher leaf area index at 60 DAS, 90 DAS and at harvest as compared to Narendra Rai -1 and Kranti.

Interaction between dates of sowing $\mathbf{x}$ varieties was found non-significant on leaf area index of mustard.

\section{Number of branches plant ${ }^{-1}$}

Data pertaining to number of branches plant ${ }^{-1}$ of mustard as affected by dates of sowing and varieties recorded at successive growth stages have been presented in table.

Different dates of sowing under investigation have no significant effect on number of branches plant ${ }^{-1}$ at 30 DAS. Data reveal that significantly higher number of branches plant ${ }^{-}$ 1 was recorded under $10^{\text {th }}$ November sown crop over $15^{\text {th }}$ October $\& 10^{\text {th }}$ November and at par with $15^{\text {th }}$ October at 60 DAS \& 90 DAS. Whereas, at harvest the number of branches plant $^{-1}$ was recorded significantly higher with $10^{\text {th }}$ November sown crop over $05^{\text {th }}$ December and at par with $15^{\text {th }}$ October \& $15^{\text {th }}$ October sowing dates. Delayed, sowing by one month produced lower number of branches plant ${ }^{-1}$ at all the stages of mustard crop.

Varieties had no significant effect on number of branches plant $^{-1}$ at 30 DAS. Variety Varuna recorded statistically highest number of branches plant ${ }^{-1}$ at 60, 90 DAS and at harvest.

Interaction between dates of sowing $\mathrm{x}$ varieties was found non-significant on number of branches plant ${ }^{-1}$ of mustard.

\section{Dry matter accumulation (g plant ${ }^{-1}$ )}

Data with respect to dry matter accumulation as affected by dates of sowing and varieties recorded at successive growth stages have been presented in Table.4. 
Perusals of the data obviously reveal that the dry matter accumulation increased successively with age of the crop till the harvest. It is obvious from the data revealed that dry matter accumulation was significantly influenced by different dates of sowing. Different dates of sowing have no significant effect on dry matter accumulation plant ${ }^{-1}$ at 30
DAS. Higher dry matter accumulation was recorded under $10^{\text {th }}$ November sowing over 05th ${ }^{\mathrm{h}}$ December and at par with $15^{\text {th }}$ October and at 60 DAS and 90 DAS. Whereas, at harvest dry matter accumulation was at par with $15^{\text {th }}$ October and significantly higher over 05 December sowing.

Table.1 Initial plant population and plant height as influenced by different date of sowing and varieties

\begin{tabular}{|c|c|c|c|c|c|}
\hline \multirow[t]{2}{*}{ Treatments } & \multirow{2}{*}{$\begin{array}{c}\text { IPP } \\
\text { meter }^{-2} \text { at } 20 \\
\text { DAS }\end{array}$} & \multicolumn{4}{|c|}{ plant height (cm) } \\
\hline & & 30 DAS & 60 DAS & 90 DAS & $\begin{array}{c}\text { At } \\
\text { harvest }\end{array}$ \\
\hline \multicolumn{6}{|l|}{ Date of sowing } \\
\hline 15 Oct 2018 & 13.3 & 20.5 & 64.8 & 133.2 & 162.1 \\
\hline 10 Nov 2018 & 14.6 & 23.9 & 72.4 & 137.5 & 165.4 \\
\hline 05 Dec 2018 & 12.3 & 19.4 & 62.3 & 125.1 & 152.3 \\
\hline SEm \pm & 0.33 & 0.42 & 1.38 & 2.45 & 3.25 \\
\hline $\mathrm{CD}(\mathrm{P}=0.05)$ & NS & NS & 4.71 & 8.47 & 12.14 \\
\hline \multicolumn{6}{|l|}{ Varieties } \\
\hline Varuna & 16.1 & 23.66 & 76.14 & 142.12 & 171.12 \\
\hline Narendra Rai-1 & 15.8 & 23.15 & 68.58 & 129.44 & 155.38 \\
\hline Kranti & 15.1 & 22.44 & 61.07 & 119.66 & 147.44 \\
\hline SEm \pm & 0.33 & 0.45 & 1.49 & 3.10 & 3.72 \\
\hline $\mathrm{CD}(\mathrm{P}=0.05)$ & NS & NS & 4.38 & 9.27 & 11.11 \\
\hline
\end{tabular}

Table.2 Days taken to 50\% flowering and Leaf area index as influenced by different date of sowing and varieties

\begin{tabular}{|c|c|c|c|c|}
\hline \multirow[b]{2}{*}{ Treatments } & \multirow{2}{*}{$\begin{array}{l}\text { Days taken to } \\
50 \% \text { flowering }\end{array}$} & \multicolumn{3}{|c|}{ Leaf area index } \\
\hline & & 30 DAS & 60 DAS & 90 DAS \\
\hline \multicolumn{5}{|l|}{ Date of sowing } \\
\hline 15 Oct 2018 & 49.0 & 1.7 & 4.4 & 3.2 \\
\hline 10 Nov 2018 & 51.0 & 1.9 & 4.6 & 3.6 \\
\hline 05 Dec 2018 & 47.25 & 1.6 & 4.3 & 3.1 \\
\hline SEm \pm & - & 0.046 & 0.08 & 0.08 \\
\hline $\mathrm{CD}(\mathrm{P}=0.05)$ & - & NS & 0.34 & 0.21 \\
\hline \multicolumn{5}{|l|}{ Varieties } \\
\hline Varuna & 49.08 & 1.6 & 4.8 & 3.7 \\
\hline Narendra Rai-1 & 47.05 & 1.4 & 4.4 & 3.2 \\
\hline Kranti & 46.06 & 1.3 & 3.7 & 2.6 \\
\hline SEm \pm & - & 0.02 & 0.07 & 0.06 \\
\hline $\mathrm{CD}(\mathrm{P}=0.05)$ & - & NS & 0.24 & 0.23 \\
\hline
\end{tabular}


Table.3 Number of branches plant ${ }^{-1}$ as influenced by different date of sowing and varieties

\begin{tabular}{|c|c|c|c|c|}
\hline \multirow[t]{2}{*}{ Treatments } & \multicolumn{4}{|c|}{ No. of branches plant ${ }^{-1}$} \\
\hline & 30 DAS & 60 DAS & 90 DAS & At harvest \\
\hline \multicolumn{5}{|l|}{ Date of sowing } \\
\hline 15 Oct 2018 & 2.0 & 16.8 & 21.7 & 20.4 \\
\hline 10 Nov 2018 & 2.2 & 18.3 & 22.5 & 20.7 \\
\hline 05 Dec 2018 & 1.9 & 16.2 & 20.7 & 19.8 \\
\hline $\mathrm{SEm} \pm$ & 0.06 & 0.25 & 0.41 & 0.52 \\
\hline $\mathrm{CD}(\mathrm{P}=0.05)$ & NS & 1.01 & 1.47 & 1.81 \\
\hline \multicolumn{5}{|l|}{ Varieties } \\
\hline Varuna & 2.2 & 19.1 & 23.0 & 22.0 \\
\hline Narendra Rai-1 & 2.1 & 16.2 & 20.4 & 20.1 \\
\hline Kranti & 2.0 & 14.6 & 17.9 & 17.1 \\
\hline SEm \pm & 0.05 & 0.32 & 0.34 & 0.43 \\
\hline $\mathrm{CD}(\mathrm{P}=0.05)$ & NS & 0.97 & 1.11 & 1.28 \\
\hline
\end{tabular}

Table.4 Dry matter accumulation as influenced by different date of sowing and varieties

\begin{tabular}{|c|c|c|c|c|}
\hline \multirow[t]{2}{*}{ Treatments } & \multicolumn{4}{|c|}{ Dry matter accumulation (g plant ${ }^{1}$ ) } \\
\hline & 30 DAS & 60 DAS & 90 DAS & At harvest \\
\hline \multicolumn{5}{|l|}{ Date of sowing } \\
\hline 15 Oct 2015 & 1.7 & 15.5 & 34.5 & 39.9 \\
\hline 10 Nov 2018 & 1.9 & 15.8 & 35.9 & 43.0 \\
\hline 05 Dec 2018 & 1.4 & 13.5 & 30.4 & 35.3 \\
\hline SEm \pm & 0.06 & 0.45 & 0.78 & 0.82 \\
\hline $\mathrm{CD}(\mathrm{P}=0.05)$ & NS & 1.6 & 2.75 & 2.78 \\
\hline \multicolumn{5}{|l|}{ Varieties } \\
\hline Varuna & 1.9 & 16.6 & 36.8 & 42.6 \\
\hline Narendra Rai-1 & 1.8 & 14.8 & 33.3 & 38.7 \\
\hline Kranti & 1.6 & 13.1 & 29.4 & 34.3 \\
\hline $\mathrm{SEm} \pm$ & 0.13 & 0.34 & 0.58 & 0.89 \\
\hline $\mathrm{CD}(\mathrm{P}=0.05)$ & NS & 1.02 & 1.76 & 2.65 \\
\hline
\end{tabular}

Table.5 Yield attributes as influenced by different date of sowing and varieties

\begin{tabular}{|l|c|c|c|c|}
\hline \multicolumn{1}{|c|}{ Treatments } & $\begin{array}{c}\text { Number of } \\
\text { siliquae plant }\end{array}$ & $\begin{array}{c}\text { Length of } \\
\text { siliqua }(\mathbf{c m})\end{array}$ & $\begin{array}{c}\text { Number of seeds } \\
\text { Siliqua }^{-1}\end{array}$ & $\begin{array}{c}\text { 1000-ssed weight } \\
(\mathbf{g})\end{array}$ \\
\hline Date of sowing & & & & \\
\hline 15 Oct 2018 & 265.3 & 6.7 & 11.2 & 4.3 \\
\hline 10 Nov 2018 & 286.0 & 7.8 & 11.5 & 4.5 \\
\hline 05 Dec 2018 & 263.7 & 6.1 & 10.1 & 3.9 \\
\hline SEm \pm & 7.15 & 0.15 & 0.25 & 0.08 \\
\hline CD (P=0.05) & 26.73 & 0.66 & 0.76 & NS \\
\hline Varieties & & & & 4.4 \\
\hline Varuna & 299.2 & 7.6 & 12.5 & 4.3 \\
\hline Narendra Rai-1 & 269.6 & 6.8 & 10.5 & 4.1 \\
\hline Kranti & 237.4 & 6.2 & 9.7 & 0.04 \\
\hline SEm \pm & 5.66 & 0.11 & 0.24 & NS \\
\hline CD (P=0.05) & 17.44 & 0.45 & 0.74 & \\
\hline
\end{tabular}


Table.6 Seed yield, stover yield and harvest index as influenced by different date of sowing and varieties

\begin{tabular}{|c|c|c|c|}
\hline Treatments & Seed yield $\left(\mathrm{kg} \mathrm{ha}^{-1}\right)$ & Stover yield $\left(\mathrm{kg} \mathrm{ha}^{-1}\right)$ & Harvest index (\%) \\
\hline \multicolumn{4}{|l|}{ Date of sowing } \\
\hline 15 Oct 2018 & 1749.5 & 6058.5 & 23.1 \\
\hline 10 Nov 2018 & 1849.7 & 6475.9 & 23.8 \\
\hline 05 Dec 2018 & 1631.5 & 5628.7 & 21.2 \\
\hline SEm \pm & 53.98 & 151.69 & 0.42 \\
\hline $\mathrm{CD}(\mathrm{P}=0.05)$ & 187.77 & 525.88 & $\mathrm{NS}$ \\
\hline \multicolumn{4}{|l|}{ Varieties } \\
\hline Varuna & 1878.8 & 6534.7 & 22.5 \\
\hline Narendra Rai-1 & 1778.9 & 6186.8 & 22.4 \\
\hline Kranti & 1522.4 & 5272.3 & 22.3 \\
\hline SEm \pm & 42.31 & 151.85 & 0.51 \\
\hline $\mathrm{CD}(\mathrm{P}=0.05)$ & 126.74 & 449.11 & NS \\
\hline
\end{tabular}

Table.7 Oil content, oil yield, nitrogen content and protein content as influenced by different date of sowing and varieties

\begin{tabular}{|c|c|c|c|c|}
\hline Treatments & Oil content (\%) & Oil yield (kg) & $\begin{array}{l}\text { Nitrogen content } \\
(\%)\end{array}$ & Protein content (\%) \\
\hline \multicolumn{5}{|l|}{ Date of sowing } \\
\hline 15 Oct 2018 & 39.8 & 736.5 & 3.3 & 22.3 \\
\hline 10 Nov 2018 & 40.6 & 838.8 & 3.6 & 22.8 \\
\hline 05 Dec 2018 & 37.3 & 624.5 & 2.9 & 19.2 \\
\hline SEm \pm & 0.79 & 20.83 & 0.07 & 0.68 \\
\hline $\mathrm{CD}(\mathrm{P}=0.05)$ & 2.88 & 72.45 & 2.17 & 2.24 \\
\hline \multicolumn{5}{|l|}{ Varieties } \\
\hline Varuna & 41.6 & 842.2 & 3.6 & 21.6 \\
\hline Narendra Rai-1 & 40.8 & 782.8 & 3.5 & 22.7 \\
\hline Kranti & 37.7 & 609.5 & 3.3 & 19.3 \\
\hline SEm \pm & 0.85 & 18.37 & 0.48 & 0.57 \\
\hline $\mathrm{CD}(\mathrm{P}=0.05)$ & 2.68 & 54.62 & 1.57 & 1.69 \\
\hline
\end{tabular}

Among the varieties Varuna recorded significantly higher dry matter accumulation at 60, 90 DAS and at harvest as compared to Narendra Rai -1 and Kranti respectively.

Interaction between dates of sowing $\mathrm{x}$ varieties was found non-significant on dry matter accumulation of mustard.

\section{Yield attributes and Yield}

Yield parameters viz. number of siliquae plant $^{-1}$, length of siliqua $(\mathrm{cm})$, number of seeds siliqua ${ }^{-1}, 1000$ seed weight, seed yield $\left(\mathrm{kg} \mathrm{ha}{ }^{-1}\right)$, stover yield $\left(\mathrm{kg} \mathrm{ha}^{-1}\right)$ and harvest index as influenced by dates of sowing and varieties of mustard are presented in Table 4.5-4.6.

\section{Number of siliquae plant ${ }^{-1}$}

Data pertaining to number of siliquae plant $^{-1}$ as affected by dates of sowing and varieties have been presented in Table 4.5. Data reveal that dates of sowing and varieties had significant influence on the number of siliquae plant ${ }^{-1}$. 
Number of siliquae plnat ${ }^{-1}$ was significantly influenced due to dates of sowing. Significantly higher number of siliquae plant ${ }^{-1}$ was recorded when crop sown on $10^{\text {th }}$ November over $05^{\text {th }}$ December and at par with $15^{\text {th }}$ October. Delayed, sowing by one month produced the lowest number of siliquae plant

Number of siliquae plant ${ }^{-1}$ was significantly affected due to varieties. A critical examination over data quite reveal that among the varieties Varuna recorded significantly higher number of siliquae plant ${ }^{-1}$ as compared to Narendra Rai -1 and Kranti.

Interaction effect between dates of sowing $\mathbf{x}$ varieties was found non-significant on number of siliquae plant ${ }^{-1}$ of mustard.

\section{Length of siliqua $(\mathrm{cm})$}

Data pertaining to length of siliqua of mustard as affected by dates of sowing and varieties have been presented in Table 4.5. Data reveal that date of sowing and varieties had significant influence on the length of siliqua of mustard.

Different dates of sowing under investigation brought significant influence on the length of siliqua. Crop sown on $10^{\text {th }}$ November recorded significantly higher length of siliqua while at par with $15^{\text {th }}$ October sowing, length of siliqua was recorded lowest with $05^{\text {th }}$ December sowing of mustard.

Length of siliqua was significantly influenced due to varieties. Among the varieties Varuna recorded significantly higher length of siliqua as compared to Narendra Rai - 1 and Kranti.

Interaction effect between dates of sowing $\mathbf{x}$ varieties was found non-significant on length of siliqua of mustard.

\section{Number of seeds siliqua ${ }^{-1}$}

Data pertaining to number of seeds siliqua ${ }^{-1}$ of mustard as affected by dates of sowing and varieties have been presented in Table 4.5. Data reveal that date of sowing and varieties had significant influence on the number of seeds siliqua ${ }^{-1}$ of mustard.

Different dates of sowing under investigation brought significant influence on the number of seeds siliqua $^{-1}$. Crop sown on $10^{\text {th }}$ November recorded significantly higher length of siliqua. while at par with $05^{\text {th }}$ December, number of seeds siliqua ${ }^{-1}$ was recorded lowest under with 15 October sowing of mustard.

Number of seeds siliqua ${ }^{-1}$ was significantly influenced due to varieties. Among the varieties, Varuna recorded significantly higher length of siliqua as compared to Narendra Rai -1 and Kranti.

Interaction effect between dates of sowing $\mathbf{x}$ varieties was found non-significant on number of seeds siliqua ${ }^{-1}$ of mustard.

\section{0 seed weight $(\mathrm{g})$}

Data pertaining to one thousand seed weight of mustard as affected by dates of sowing and varieties have been presented in Table 4.5. 1000 seed weight of mustard was not influenced significantly due to dates of sowing.

Seed weight of mustard was not significantly influenced due to varieties. However, variety Varuna recorded statistically highest 1000 seed weight.

Interaction effect between dates of sowing $\mathrm{x}$ varieties was found non-significant on 1000 seed weight of mustard. 


\section{Seed yield $\left(\mathrm{kg} \mathrm{ha}^{-1}\right)$}

Data pertaining to seed yield of mustard as affected by dates of sowing and varieties have been presented in Table 4.6. The data reveal that date of sowing and varieties significantly influenced the seed yield of mustard.

Different dates of sowing under investigation brought significant influence on the seed yield. Crop sown on $10^{\text {th }}$ November recorded significantly higher seed yield over $15^{\text {th }}$ October sowing while at par with 05 December sowing. The seed yield was recorded lowest under $15^{\text {th }}$ October sowing of mustard.

Seed yield was significantly influenced due to varieties. Among the varieties Varuna recorded significantly higher seed yield as compared to Kranti and at par with Narendra Rai -1.

Interaction effect between dates of sowing $\mathbf{x}$ varieties was found non-significant on Seed yield of mustard.

\section{Stover yield (kg ha $\left.{ }^{-1}\right)$}

Data pertaining to Stover yield of mustard as affected by dates of sowing and varieties have been presented in Table 4.6. The data reveal that date of sowing and varieties had significantly influenced the stover yield of mustard. Different dates of sowing under investigation brought significant influence on the Stover yield. Crop sown on $10^{\text {th }}$ November recorded significantly higher stover yield over $15^{\text {th }}$ October and sowing while at par with 05 December sowing, stover yield was recorded lowest under with $15^{\text {th }}$ October sowing of mustard.

Stover yield was significantly influenced due to varieties. Among the varieties Varuna recorded significantly higher stover yield as compared to Kranti and at par with Narendra Rai -1.

Interaction effect between dates of sowing $\mathbf{x}$ varieties was found non-significant on stover yield of mustard.

\section{Harvest index}

Data pertaining to harvest index of mustard as affected by dates of sowing and varieties have been presented in Table 4.6. Harvest index of mustard was not influenced significantly due to dates of sowing and varieties.

Interaction effect between dates of sowing $\mathbf{x}$ varieties was found non-significant on harvest index of mustard.

\section{Quality}

\section{Oil content (\%)}

Data pertaining to oil content of mustard as affected by dates of sowing and varieties have been presented in Table 4.7. Oil content of mustard was not influenced significantly due to dates of sowing and varieties.

Interaction effect between dates of sowing $\mathbf{x}$ varieties was found non-significant on oil content of mustard.

\section{Oil yield (kg)}

Data pertaining to oil yield of mustard as affected by dates of sowing and varieties have been presented in Table 4.7. Dates of sowing had significantly influenced the oil yield of mustard.

A critical examination over data obviously reveal that the crop sown on $10^{\text {th }}$ November produced significantly higher oil yield as compared to $15^{\text {th }}$ October sowing and at par with 05 December sowing. 
Oil yield was significantly influenced due to varieties. Among the varieties, Varuna recorded significantly higher amount of oil yield as compared to Narendra Rai -1 and Kranti.

Interaction effect between dates of sowing $\mathbf{x}$ varieties was found non-significant on oil yield of mustard.

\section{References}

Anonymous, 2013-14. Directorate of Economics and Statistics, Department of Agriculture and Cooperation (DAC). Chapter 8 Table 8.2, 138 and Mustard Crop Survey Report 2014- 15.

Bharadwaj, G.S., 1991. Response of mustard (B. juncea) varieties to nitrogen in north Madhya Pradesh. Indian J. Agron., Indian Journal of Agronomy 26(3), 382-384.

Chaplot, P.C., Vandeep, A., Kumar, R., 2012. Effect of balanced fertilization and Agrochemcials on growth, yield attributes and yield of mustard varieties. 3rd International Agron., Con., Nov., International Agronomy Conference. Nov., 26-30, New Delhi, 1110-1111.

Khusbhu, M.K., Singh, M., 2005. Thermal response of mustard under rainfed condition of Jammu. Env. And Ecol. Environment and Ecology 23(3), 683686. Kumar, P., Kumar, M., Singh, A.P., Mamta, Elamathi, S., 2015. Economics and quality parameters of toria varieties influenced by sowing dates and sulphur levels. Plant Archives 15(2), 1021-1024.

Kumar, R., Singh, D., Singh, H., 2000. Growth and yield of Brassica species as influenced by sulphur application and sowing dates. Indian J. Agron., Indian Journal of Agronomy 47(3), 417-421.

Kurmi, K., 2002. Influence of sowing date on the performance of rapeseed and mustard varieties under rainfed situation of Southern Assam. J. of Oilseeds Res. Journal of Oilseeds Research 19(2), 197-198.

Panda, B.B., Bandyopadhyay, S.K., Shivayy, Y.S., 2004. Effect of irrigation level, sowing dates and varieties on growth, yield attributes, yield, consumptive water use and water use efficiency of Indian mustard (Brassica juncea L.). Indian J. of Agri. Sci. Indian Journal of Agricultural Sciences 74(6), 331-342.

Panwar, K.S., Sharma, S.K., Nanwal, R.K., 2000. Influence of sowing time on the yield of different mustard cultivars (Brassica spp.) under conserved soil moisture condition. Indian J. of Agri. Sci. Indian Journal of Agricultural Sciences 70(6), 398-399.

Singh, A.K., Yeshpal, R.P., 2011. Performance of mustard hybrids under different sowing dates and spacings. Pantnagar Journal of Research 9(1), 1619.

Singh, H.R., 1989. Effect of nitrogen and row spacing on growth yield and quality of mustard varieties (Brassica juncea $L$. Czern\&Coss.). M.Sc. (Ag.) thesis submitted to N.D. Univ. of Agri. \& Tech., Narendra Nagar, Kumarganj, Faizabad (U.P.).

Singh, R., Patidar, M., Singh, B., 2001. Response of Indian mustard cultivars to different sowing time. Ind. J. of Agron. Indian Journal of Agronomy 46(2), 292-295 Singh, S.K., Singh, G., 2002. Response of Indian mustard (Brassica juncea) varieties to nitrogen under varying sowing dates in eastern Uttar Pradesh. Indian J. Agron. Indian Journal of Agronomy 47(2), 242-248.

Thakur, K.S., Singh, C.M., 1998. Performance of Brassica species dates of sowing in mid hills of Himachal Pradesh. Ind. J. of Agron. Indian Journal of Agronomy 43(3), 464-468. 


\section{How to cite this article:}

Kul Bhushan Mani Tripathi, Tarun Gaur, Lovkush Pandey, Ajay Singh, Ankit Tiwari, Ved Prakash, Utkarsh Singh Rathore and Rohit Kumar Singh. 2021. Effect of Sowing Dates on Growth and Yield of Indian Mustard (Brassica juncea L.). Int.J.Curr.Microbiol.App.Sci. 10(01): 3046-3057. doi: https://doi.org/10.20546/ijcmas.2021.1001.355 